\title{
The Concept and Practice of Social Enterprise. Lessons from the Italian Experience
}

\author{
Carlo BORZAGA \\ European Research Institute on Cooperative and Social Enterprises (Euricse) \\ University of Trento \\ Giulia GALERA` \\ European Research Institute on Cooperative and Social Enterprises (Euricse)
}

\begin{abstract}
Social enterprises are increasingly regarded as successful mechanisms for reconciling equity and efficiency with the crea $\neg$ tion of economic and social value, and they can be interpreted as concrete expressions of a growing sense of social responsibility on the part of citizens. Research conducted in various geographical contexts corroborates that social enterprises are a structural trend, which cuts across countries with diverse characteristics. Following a historical contextualization of the social enterprise, the article focuses on a conceptual analysis. Next, attention is paid to the diffusion of social enterprises in the enlarged Europe, including countries where social enterprises have been acknowledged; countries where social enterprises are increasingly regarded as a unique way whereby unmet needs can be addressed; and countries where social enterprise-like initiatives happen to emerge despite the predominance of unfavourable conditions. Finally, attention is paid to social enterprises in Italy and specifically to the key factors explaining their success.
\end{abstract}

Keywords: social enterprise; cooperative; community engagement; decentralization of public competences; umbrella organizations; welfare system reform.

\section{Introduction}

Social enterprises are increasingly regarded as successful mechanisms for reconciling equity and efficiency with the creation of economic and social value, and they can be interpreted as concrete expressions of a growing sense of social responsibility on the part of citizens, which cuts across countries with profoundly diverse characteristics in terms of welfare systems, levels of economic development, and degrees of democratization.

When looking at the context of development of social enterprises, several initiatives developed to respond to new needs that were ignored

•e-mail: giulia.galera@euricse.eu. 
by for-profit enterprises and were not adequately addressed by public policies. Many social enterprises were indeed initially started as groups of volunteers or self-help groups of local communities and managed to organize concrete responses by instigating entrepreneurial initiatives and mobilizing a mix of resources. They have responded to new and unmet needs, often relying substantially on voluntary work, especially in the startup phases (Borzaga and Becchetti, 2011).

Research conducted in various geographical contexts corroborates that social enterprises are a structural trend, which tends to develop spontaneously independently from the existence of exogenous enabling conditions; hence the global dimension of this bottomup reaction on the part of groups of citizens, on the one hand, and also the heterogeneous development trends characterizing social enterprises, which depend on the interplay among various forces at play. Especially delicate is the relation of social enterprises with public policies. Indeed, social enterprises can be sustained through adequate supporting and funding schemes, which are introduced on the ground of the responsibilities such institutions decide to take on. When this is the case, policies contribute to addressing weaknesses and enhancing strengths of social enterprises, ensuring thus the replication of social enterprises and the multiplication of their beneficial impacts upon local communities. By contrast, the spontaneous bottom-up dynamic pushing groups of citizens to self-organize, has also been jeopardized by inadequate policies, which prevented the balanced expansion of social enterprises. Where their potential is not fully harnessed, social enterprise-like initiatives are condemned to remain isolated initiatives. This is still the case of a considerable number of countries, both EU and non EU, including among others Central Eastern and South Eastern European countries.

The roles displayed by social enterprises in Central Eastern and South Eastern Europe are still widely underestimated. Various factors can contribute to explaining their insufficient development vis-à-vis the demand for general-interest services and the adoption of entrepreneurial behaviours on the part of groups of people, including the lack of supporting environments and infrastructures, a restricted access to resources, unsuitable institutional framework and inconsistent legal environment, which result in a lack of legal regulations and unsuitable legal frameworks that fail to consider the social commitment and degree of disadvantage taken on by social enterprises into account. In addition, the fragile political systems where social enterprises are fit in prevent them from building medium and longer term strategies and the lack of skills of social entrepreneurs adds to the chronic financial instabilities of most social enterprises. Overall, the roles displayed by other than investor-owned organizations and public agencies in the social systems and economies of post-communist countries are widely untapped. Social enterprises are still considered as 'filling the gaps' agents rather than long-term welfare and economic actors (Leś and Jeliazkova, 2007).

Given these considerations, reflecting on the social enterprise 
experience in Europe, particularly in Italy, can contribute to providing arguments for supporting the development of such institutions in central Eastern European countries.

\section{The roots of social enterprises}

Social enterprises are normally described as a recent phenomenon. Nevertheless, these private entrepreneurial initiatives that are characterized by explicit social goals are grounded in the long-standing European tradition of cooperatives, charities and non-profit organizations.

Organizations other than investorowned and public agencies existed for centuries, but they started to develop more intensively in the middle of the $19^{\text {th }}$ century all over Europe, following the process of democratization, industrialization, nation-state building, and the development of social movements. Social enterprises have roots in the history of self-organization though charities linked to the churches or mutual aid organizations in worker movements, as well as associations and self-help groups, which were all characterized by direct forms of participation of producers and users in goods and services delivery (Evers, 1998). Against this background, the cooperative movement succeeded in combining the principles of economic security, social freedom, and political participation (Pankoke, 2004).

Historically, consumer cooperatives, agricultural cooperatives, mutual-aid societies, credit unions, and saving banks were set up in many localities, both in western and eastern Europe, while other types of cooperatives were consolidated in specific countries: housing cooperatives in Germany, the United Kingdom, and Sweden; in countries such as France and Italy, which were characterised by a slower industrialisation process, workers' production cooperatives took root (CIRIEC, 1999).

At the end of the $19^{\text {th }}$ century cooperatives performed an important role as economic and social institutions also in central and eastern Europe. Interesting examples of self-reliance initiatives could be found in the Czech Republic, Bulgaria, Serbia, and Poland (Borzaga, Galera and Nogales, 2008).

The first cooperative experiences were a spontaneous defensive response on the part of the working class to the harsh conditions dictated by the industrial revolution (Monzòn Campos, 1997). Mutual aid societies were set up by workers and trade unions to provide common insurance and assistance. By promoting the interests of their members, cooperatives contributed to improving the quality of life of large disadvantaged segments of society. Noteworthy is that cooperatives were originally not only economic institutions, but also social institutions recreating solidarity and collective selfhelp. Raiffeisen's idea of a Christianity of action, Schulze-Delitzsch's concept of self-help in order to strengthen the individual, the Rochdale Pioneer's aim of emancipating workers, and Victor Huber's proposal of active self-education demonstrate the social dimension of cooperatives (Todev, Brazda and Schediwy, 1993). Indeed, the meaning of the cooperative movement was expressed by the slogan 'one for all, and all for one', which emphasizes the concept of 
solidarity that it incorporates. In all the aforementioned cases, the driving objective of the entrepreneurial activity and the salient characteristic of the corporate culture embedded were the sharing of a common social ideal, including solidarity, equality, and justice.

Alongside the development of a vibrant cooperative sector in all European countries, the system of charitable service provision dating back to the Middle Ages gained an important role. Charities and other types of nonprofit organizations spread in the health and social service sectors and covered a relevant role until they were replaced by a system of public welfare services (Anheier, 2005).

Since the beginning of the $20^{\text {th }}$ century, as a result of the development of fledging welfare states, the fight against poverty, and the promotion of the weakest segments of the population, the public interest and the redistributive functions, alongside most social and health services, have been increasingly taken on by the central and local government. Thus, key social goods were removed from private control and started to be provided by law to all citizens and funded by public funds through the setting up of a central administration and a new cadre of civil servants (Walzer, 1998). As a result of the expansion of both the welfare states and trade union movements, as well as the development of competitive markets in a number of economic sectors, poverty became increasingly less pressing.

State involvement in welfare became a prominent feature internationally accepted (Glennerster and Midgley, 1991). The primary responsibility assumed by the government was that of reducing inequalities and facing the most difficult social problems affecting industrial societies. Furthermore, with regard to public goods, the redistribution of services was ensured through the provision of free or lowpriced services by public institutions. Accordingly, the first step in welfare redistribution was ensured by tax policies, since tax rates were adjusted to the income level of the taxpayer.

It can be said that, while on the one hand the development of welfare states coupled with the expansion of markets and trade unions have strengthened the presence of politics in the social life of a political community, on the other hand it has weakened associations, mutual aid societies, cooperatives, and voluntary agencies engaged in building up social services and promoting activities of various kinds for the community (Evers and Laville, 2004). The working-class 'friendly societies' that provided their members with the earliest form of social security collapsed (Walzer, 1988). Private charities and voluntary organizations, especially those committed to service provision declined or were incorporated into state-controlled welfare systems. In some countries, for instance the United Kingdom, traditional third sector organizations kept a specialist role in some fields, which were not seen as a priority by the state, and developed a complementary role in others (Taylor, 2004). However, the overall role of associations and active membership in mutual aid societies and cooperatives became of decreasing importance (Evers and Laville, 2004). This can be ascribed to the circumstance that all western countries were involved in the 
process of creating and consolidating the nation-states and they followed the project of nationalization of distribution, albeit shaping their welfare systems consistently with their political, cultural, and ideological characteristics (Rodger, 2000). In central eastern European countries, the Soviet and post-World War II periods were very unfavourable for those organizations that had been founded on the principles of autonomy, solidarity, participation, and mutuality. Cooperative enterprises became an integral part of the political system and planned economy (Lès and Jeliazkova, 2007), while foundations were incorporated into the public infrastructure (Borzaga, Galera and Nogales, 2008).

\section{Conceptual issues}

Over the last decade, the concept of social enterprise has made amazing breakthroughs on both sides of the Atlantic, especially in EU countries and the United States. It is also attracting increasing interest in other regions of the world such as former Soviet Union countries, Eastern Asia and Latin America (Defourny and Nyssens, 2008).

However, it should be recalled that the term social enterprise was used for the first time in Europe, precisely in Italy in the 1980 s, to identify the innovative private initiatives established by volunteer groups that had formed to deliver social services or provide economic activities designed to facilitate the integration of disadvantaged people. At about the same time, organizations sharing similar goals were developing in a number of other European countries. These initiatives were initially set up using the not-for-profit legal forms made available by national legal systems (associations, foundations or cooperatives), which were in some cases modified to allow them to combine entrepreneurial activities with the pursuit of social aims. As a result, in some countries such as France and Belgium, the most of these organizations adopted associative forms, while in other countries, such as Italy, they adopted the cooperative forms, giving rise to social cooperatives.

In Europe, the term social enterprise is hence used to describe a 'different way' of doing business and also of providing social services, which encompasses the more entrepreneurial component of the non-profit sector and innovative component of the cooperative movement. A specific feature of the European social enterprise concept is the setting up of an institutional structure specifically designed to pursue a social goal in a stable and continuous way through the production of goods or services of general-interest. As such, this approach is regarded as extremely revolutionary because it challenges traditional assumptions held by conventional economic theory, including the shared conception of enterprises as organizations promoting the exclusive interests of their owners.

The most comprehensive definition of social enterprise has been elaborated by the EMES European Research Network (Borzaga and Defourny, 2001; Defourny and Nyssens, 2008). This definition is broadly accepted by academics and has inspired several 
pieces of legislation designed to regulate these forms of enterprises, as well as the recent initiative of the EU Commission on the Social Business. The definition was initially elaborated along two dimensions (the economicentrepreneurial and social dimensions). Following an intense scientific debate and the introduction of recent laws on social enterprises, this definition can be more precisely structured along three axis: the economic-entrepreneurial, the social, and the ownership-governance.

The economic-entrepreneurial dimension takes for granted that social enterprises show the typical features of an enterprise. Accordingly, social enterprises must: be engaged in the stable and continuous production of goods or services; rely -at least partially - to the use of costly production factors (e.g. paid work), and take a significant level of economic risk.

The social dimension presupposes that social enterprises pursue an explicit social aim of serving the community or a specific group of people through the production of goods/services characterized by a general-interest or meritorial nature. Given the contextspecificity of the concept of 'meritorial good', which depends on the judgment of a given society, the typology of services supplied can vary to a great extent. According to the diversity of unmet needs that may arise at local level in different countries and contexts the set of services delivered can comprehend welfare, health, educational, cultural services up to economic-general interest services (e.g. water supply, gas, electricity).

The ownership-governance dimension presupposes that: social enterprises are characterized by collective dynamics involving people belonging to a community or to a group that shares a certain need or aim; the adoption of decision-making processes not based on capital ownership and ensuring the participation of all relevant stakeholders; and the compliance with a total or a partial non-distribution constraint such that the organization distributes profits only to a limited extent, thus avoiding profit-maximising behaviour. The participatory and inclusive governance promoted is precisely aimed at strengthening the social orientation of the enterprise, on the one hand, and supporting a fair distribution of incentives, on the other hand. The mentioned criteria are meant to allow for an effective identification of new needs emerging at a community level and help creating trust relations among the stakeholders concerned.

This definition does not refer to a specific national legal system or to precise legal forms. It conceives the social enterprise as a private and autonomous entity that operates productive activities according to entrepreneurial criteria. Differently from conventional enterprises, social enterprises pursue an explicit social goal, which implies the production of goods and services that generate direct benefits for the entire community or specific groups of disadvantaged people. This definition excludes profit maximization as a goal pursued by investors. By contrast, it implies the search of balance between the fair remuneration of labour and capital and the interest of users. Social enterprises involve various types of stakeholders such as volunteers, funders and users in its ownership and governing bodies; 
and they usually rely on a plurality of income sources, including public administrations when the services delivered are recognized as merit goods; monetary and work donations; as well as market and private demand.

As such, social enterprises can be distinguished from other types of enterprises and organizations. They differ from public enterprises because they are managed by private entities according to an entrepreneurial logic. They differ from conventional for-profit enterprises because they are characterized by goals, ownership assets, constraints, and governance modalities that exclude the maximization of owners' monetary advantages. They also differ from traditional cooperatives, which are enterprises owned by noninvestors that are principally aimed to promote the interests of their owners. Nevertheless, social enterprises are close to cooperative enterprises in terms of their ownership of assets, democratic governance structures, and common origins. This explains why social enterprises often decide to adopt cooperative forms.

This definition helps to locate social enterprises vis-à-vis nonprofit organizations. Organizations that mainly engage in advocacy activities, civic participation, or resource redistribution may be nonprofits, but they are not social enterprises. Moreover, some social enterprises could in principle be excluded from the universe of non-profit organizations on the grounds of their legal framework or because they are partially allowed to distribute profits.
The Emergence and diffusion on social enterprises

In Western Europe the development of social enterprises was mainly stimulated by the crisis of traditional welfare states and more specifically by the reaction of groups of citizens that were dissatisfied by both the public supply and market provision of social and community care services. Until the 1970s, the institutional framework hinging essentially on the state and the market worked in a rather satisfactory way. But thereafter, and especially following the persistent slowdown of economic growth, it became increasingly evident that for-profit enterprises and the public authorities were unable to cope on their own with numerous social needs, and that the family was unable to continue in its role as the provider of most personal services. According to this interpretation, the search for innovative institutional responses to the gaps in social services was boosted by a renewed vitality of civil society through organizations supported by voluntary work. For instance the first survey focused on social cooperatives in Italy found that 22.6 per cent of the organizations studied had been formed by voluntary organizations and 15.9 per cent by associations; most of the remaining organizations (61.5 per cent) were founded directly as social cooperatives by groups of people. As to the members, only 27 per cent were workers, whereas the rest were volunteers directly engaged in the activity and supporting members. Only 21 per cent of the Italian cooperatives surveyed did not have volunteers in their memberships (Borzaga, 1988; 
Borzaga and Failoni, 1990).

It can be therefore said that social enterprises arose autonomously as a specific institutional arrangement that succeeds in matching the demand for social services with supply. This phenomenon was especially impressive in countries where the provision of these services was underdeveloped, such as Italy. In countries where private non-profit organizations (mainly associations) were already involved in the provision of social services, the prevailing trend has been towards their increasing shift towards a more entrepreneurial stance and autonomy from public agencies (Bacchiega and Borzaga, 2003).

Considerable differences can be noticed across Europe as far as the development trends of social enterprises are concerned. The concept itself has not gained the same recognition in all European countries and it continues to be poorly understood in several of them. In some countries, the concept is not even part of the political agenda nor of the academic discourse outside a very small circle of experts; this is in particular the case in Germany and Austria (Defourny and Nyssens, 2008). When looking at the so called 'enlarged Europe', the development of social enterprises has occurred in more heterogeneous ways, given the existence of context-specific endogenous and exogenous enabling factors. In some countries, social enterprises have expanded widely and rapidly, whereas in other countries they have emerged later or are now in the process of developing.

For the sake of clarity, social enterprises can be classified into different clusters, according to the degree of institutionalization achieved.

\section{Legal and political recognition of social enterprises}

Cluster 1 comprehends countries where social enterprises - or a specific type of social enterprises- have been politically and legally acknowledged, either as enterprises that can provide for a wide set of general-interest services (e.g. Italy, UK, Slovenia, France etc) or as enterprises that perform in specific fields of general-interest. The recognition of social enterprises through the adoption of specific legal forms has occurred through two different legal trends: either via the adaptation of the cooperative formula or through the introduction of legal brands and categories that recognize the social commitment taken on by certain legal entities.

The trend of recognizing social enterprises via the cooperative formula was marked by the acknowledgment of specific activities (supply of social services or work integration) carried out beyond the boundaries of the cooperative membership. This trend undermines the traditional model of cooperatives, which is based on a single stake-holding system and it is supposed to promote the interests of its members (Levi, 1999). It started formally in Italy in 1991 when the Law 381 on social cooperatives provided the legislative framework for a phenomenon, which had developed spontaneously in the previous twenty years (Borzaga and Ianes, 2006).

The Italian acknowledgment of the social enterprise via the cooperative formula was followed in a number of countries, including Portugal, Spain, France, Poland and Greece. In some countries activities that can be carried 
vary, ranging from general activities (e.g. Portugal and France) up to specific ones, mainly work integration (e.g. Poland).

A contextual and most recently widespread trend has been that of introducing more general legal frameworks for social enterprises, both with respect to the activities run and legal forms admitted. Thus, starting from the institutionalization of social enterprises through specific legal forms (association and cooperative) the trend has been towards the qualification as social enterprises of various types (or all forms) of enterprises, provided that they comply with a number of criteria, including the pursuit of an explicit social goal, compliance with a partial non-profit distribution constraint, and the participatory/collective dimension of the enterprise.

This trend first appeared in Belgium where the 'social purpose company' (in French société à finalité sociale) was introduced in 1995, followed by Italy, the United Kingdom, and Slovenia. This trend is contextual to the expansion of the set of activities carried out by social enterprises, which are increasingly committed to supply general-interest services other than welfare ones, including cultural and recreational services; activities aimed at protecting and regenerating the environment; social housing; and services aimed to support the economic development of specific communities.

A similar, but more limited evolution, has taken place in Finland. The Finnish Act on Social Enterprises was introduced in 2004, but it is specifically aimed to integrate people with disabilities and long-term unemployed to work.

\section{Indirect recognition of social enterprises}

Cluster 2 refers to countries where social enterprises -albeit not officially acknowledged- are increasingly regarded as an unique way whereby unmet needs can be addressed. In such countries an evolution of nonprofit organizations towards a social enterprise model can be noticed, which is similar to the evolution occurred in some European countries in the 1980s. Some research aimed at assessing the size of social enterprises has been conducted and umbrella organizations perform in several cases lobby activities. This cluster includes several new member and associated countries like Romania, Bulgaria, Serbia, and Slovakia, where a number of policy documents mention social enterprises when speaking about strategies aimed at fighting against social exclusion or when referring to the processes of fiscal and administrative centralization and reform of social services. However, although social enterprises are mentioned in policy debates, their official acknowledgment as welfare actors has not occurred yet. In spite of the growing interest of policy makers, practitioners, and researchers, social enterprises are still not integrated into public policies; the legal environment is not enabling; and no or few public schemes supporting the development of social enterprises are available.

\section{Isolated emergence of social enterprises}

Cluster 3 includes countries where a number of social enterprise-like 
initiatives happen to emerge despite the predominance of unfavourable institutional and legal conditions (e.g. unsuitable legal frameworks; no umbrella organizations). In such countries social enterprise initiatives can be found: an indefinite number of organizations performing key activities that are of interest to local communities exist and substantially contribute to improving the welfare of local communities. Nevertheless, such institutions appear as isolated initiatives, which are normally not acknowledged as social enterprises, and tend to be 'invisible' at national level, given the lack of reliable statistics and studies. Cluster 3 countries includes Community of Independent States and a number of candidate countries.

\section{Social Enterprises in Italy}

As already highlighted, the concept of 'social enterprise' was introduced in Italy to designate those pioneering initiatives that were created thank to the institutional imagination of its promoters. Two distinctive features of these innovations are worth mentioning: (i) the search for direct participation by stakeholders through new democratic forms of management (multi-stakeholder), and (ii) the widespread use of the cooperative form in activities which in other countries are generally managed by associations and foundations.

In Italy, the first social cooperatives emerged at the end of the 1970s mainly on the initiative of small groups of volunteers and workers, who were dissatisfied by the poor provision of social and community care services.
These new initiatives were aimed at meeting the needs of groups of beneficiaries who had been disregarded by the public welfare system or served by large hybrid institutions providing standardized services.

In the 1980 s, the 'new cooperatives' innovated the supply of social services by creating new ones targeting mainly young people with social problems, the elderly, the disabled, drug addicts and the homeless. Many of these services were initially promoted by voluntary organizations, but the use of the cooperative form rapidly became widespread, especially for the management of activities to integrate disadvantaged workers into the labour market. After a number of years of development, in 1991 (with Law 381) this new type of cooperative was recognized and given the name of 'social cooperative'.

After more than 10 years of unregulated development, thanks to the organizational and lobbying capacity of these new cooperatives, their clear social orientation and the support given by the cooperative movement, in 1991 this new type of cooperatives was recognized through the introduction of Law 381. This law did not just recognize a new form of cooperative: it introduced a new type of enterprise with an explicit social (and not only mutualistic) aim. In fact, law 381 recognizes two types of social cooperative, according to whether they manage social-welfare and educational services (type-A social cooperatives) or undertake other agricultural, manufacturing or commercial activities or deliver services (other than social) for the work integration of disadvantaged 
persons (type-B social cooperatives). Both types are entrepreneurial in nature and perform productive activities. The former can only operate in the provision of social services, while the latter have a specific focus on the employment of 'disadvantaged workers', who must constitute at least 30 per cent of their employees and for whom the cooperatives are exempted from payment of national insurance contribution.

According to Law 381, the purpose of social cooperatives is to "pursue the general interest of the community in the human promotion and social integration of citizens'.

As such, social cooperatives diverge from traditional cooperatives in their objective: while traditional cooperatives are typically devoted to the satisfaction of the members' interest, social cooperatives pursue the general interest of local communities or the social integration of citizens. The prevalence of the nonprofit aim not only depends on the decision of the founding members, but is enforced by law through the partial profit distribution constraint and the prohibition to change the legal form (i.e., social cooperatives cannot demutualize and become forprofit enterprises nor can they adopt a different cooperative form).

Over the years, social cooperatives have become key players in the Italian welfare system and an important sector of the Italian economy. Ever since they were first created, these organisations have registered an average annual growth rate ranging 8 from 10 to 20 per cent. In 2008 , there were 12,428 social cooperatives, employing approximately 350,000 workers, 35,000 volunteers, and with 4,500,000 users. As a sector, social cooperatives had a turnover of 9 billion Euro, created value added for 5.3 billion Euro, and had an invested capital of 7.2 billion Euro.

The impressive development of social cooperatives has not prevented other types of third sector organizations from developing into social enterprises, including several voluntary organizations that are engaged in the provision of social services. All this explains the introduction of a more general law both as concerns the organizations that are entitled to perform social enterprise activities and the admitted fields of engagement. Against this backdrop, the new law on social enterprise (Law $118 / 2005$ ) introduces the principle of pluralism of organizational forms and it does not consider the legal form as a condition for eligibility as a social enterprise. The innovative character of the law results from both the opening towards new sectors of activity, other than welfare, and the variety of the types of enterprises eligible to become social enterprises. As said, the law crosses the boundaries of legal and organizational forms, enabling various types of organization (not only cooperatives and traditional non-profit organizations, but also investor-owned organizations, for instance) to obtain the 'legal brand' of social enterprise, provided they comply with the nondistribution constraint and organize the representation of certain categories of stakeholders, including workers and beneficiaries.

The law also provides that associations and foundations that want to be registered as social enterprises must provide evidence of their entrepreneurial nature; 
conversely, investor-owned companies applying for the social enterprise brand have to comply with certain requirements regarding the distribution of benefits (namely respecting a total non-distribution constraint) and participation of relevant stakeholders. Nevertheless, the law seems to have met with some resistance from eligible organizations, given the predominance of cultural prejudices and the lack of fiscal advantages for organizations that decide to register as social enterprises. As a consequence, the number of registered organizations appears to be rather low (769 in June 2011) compared to the number of organizations that could in principle become social enterprise (almost 120,000 according to IRIS Network Report).

\section{Key factors explaining the impressive development of social enterprises in Italy}

Social cooperatives, as key players in the Italian welfare system, are so far the most developed typology of social enterprises in Italy. Their impressive development can be traced back to a number of enabling factors, including among the others the favourable legal and political context, which created the pre-conditions allowing for the emergence and multiplication of social enterprises. Furthermore, when analysing the factors explaining the success of social enterprises in Italy, reference should also be made to some specific features shown by social cooperatives. The interplay of exogenous and endogenous key factors had a role in supporting the outstanding achievements of social enterprises, as bottom up institutional innovations promoted by groups of citizens.

\section{Exogenous factors: the legal and political context}

In addition to the legal recognition, other enabling exogenous factors had a role in supporting the development of social enterprises, including the specificities of the Italian welfare model, the process of decentralization of public competences, and the public support that was provided by means of public contracting and fiscal advantages granted to social cooperatives.

\section{The specificity of the Italian welfare model}

In order to understand the development of the social cooperatives sector, attention should be paid to the characteristics of the Italian welfare model, whose shortcomings started to become increasingly evident in the 1970s. The welfare system, which was established in Italy after the Second World War was a mix resulting from both the corporatist and universalistic models. Education (free of charge through high school) and healthcare were fully covered by public provision, but overall, the provision of social services was rather limited, given the strong prevalence of cash benefits managed by the central government. Starting with the oil crisis in the early 1970s, the slowdown of economic growth caused an increase in unemployment levels and fuelled demand for income support. At the same time, the elderly population grew, new needs connected to 
mental disability, homelessness, drug abuse, immigration, and long-term unemployment arose, and the role of the family in providing social support declined as a result of greater female participation in the labour market. The combination of all of these factors could not be tackled by means of traditional cash benefit welfare policies, and a number of citizen groups, relying heavily on volunteers, attempted to bridge the gap in the supply of social services by devising new services and new organizational forms. Since in Italy associations and foundations were not allowed to permanently engage in productive activities, some of these groups started using the legal form of the cooperative to organize the provision of social services, given that the cooperative had the full status of an enterprise; was characterised by member participation and democratic management (like many voluntary organisations); and could be set up with a very small amount of capital. Moreover, cooperatives, according to article 45 of the Italian Constitution, had a recognized social function and were consequently regulated as quasinonprofits subject to strong profit distribution constraints.

\section{The decentralization of public competences}

In the 1990s the central and local public authorities and their agencies were progressively allowed to outsource the production of services to private organisations, like social cooperatives and voluntary organizations, since they perceived that they could cope with the growing demand for services by helping independent organisations to meet it. The practice of contracting-out therefore spread and helped promote and strengthen social cooperative.

Responding to fiscal crises and the declining legitimacy of welfare systems, social cooperatives offered an appealing alternative to the provision of services by public agencies. The resulting decentralization generated new spaces for intervention by, and public resource flows to, social cooperatives. These developments contributed to consolidating the organizational models of social cooperatives under construction and stimulated a progressive concentration of social cooperatives in public markets, particularly welfare markets. The increasingly high percentage of incomes generated from public contracting accelerated the diffusion and consolidation of social cooperatives. As a result, the supply of social services also increased.

\section{Public support}

Public contracting played a crucial role in creating new markets for social enterprises and permitted to recognize the entrepreneurial character of the pioneering social enterprise initiatives, years before social cooperatives were officially recognized by law 381 . However, the process of contracting out the production of social services to social cooperatives increased substantially after the introduction of law 381/1991, given the possibility of stipulating contracts with public bodies for the delivery of services or work integration activities. The law explicitly recognizes an affinity of mission between public bodies and social cooperatives, and emphasises 
the possibility of collaboration between them. Preferential purchasing has been a key element in the growth of social cooperatives.

Furthermore, specific tax breaks and benefits have been introduced by law 381/1991 in order to acknowledge the social responsibilities taken on by social cooperatives, including tax exemption of reserves accumulated by social cooperatives, the nil rate or four 4 per cent VAT charged by A type social cooperatives ( 20 per cent is the standard VAT rate) and the exemption from payment of national insurance contribution for disadvantaged members integrated by B type social cooperatives.

\section{Endogenous factors: the specific features of Italian social enterprises}

Additional conducive factors include some endogenous factors, namely a number of specific features shown by Italian social enterprises, which have contributed to the success of the social enterprise as a viable enterprise strongly rooted at local level.

\section{Community engagement}

Differently from some other European national experiences supporting the idea that social enterprises in Europe were mainly created by public authorities, the Italian case demonstrates that social enterprises developed as voluntary responses to social needs. They are mainly promoted by groups of citizens, who often engage as volunteers especially in the start-up phase. Recent research corroborates that also when supported by public resources, social enterprises continue to be voluntary promoted by groups of citizens. This is true for the 75.5 per cent of social cooperatives created in the 1990s and for 66 per cent of social cooperatives created after year 2000 . The strong involvement of volunteers -almost 30,000- strengthens the local embodiment of social cooperatives and their capacity to grasp unmet needs arising in society.

\section{Multi-stakeholder structure}

A key element of the strength of Italian social cooperatives is the high level of involvement of diverse types of stakeholders in the decisionmaking process and the emergence of multi-stakeholder governance. Social cooperatives were the first to move to a full involvement of their main stakeholders in their governance structure. This practice is particularly noteworthy if we consider that the Italian law on social cooperatives does not oblige them to be multistakeholder - it simply allows them to be. Nonetheless, a research carried out in 2006 showed that 69.7 per cent of Italian social cooperatives had multi-stakeholder membership (20.2 per cent also included other firms and people other than clients and volunteers as members) and 33.8 per cent of them had a multi-stakeholder governance (including different types of stakeholders not just in their membership but also in their board of directors). The main model consisted in membership involving volunteers and workers (37.9), who declared high levels of job satisfaction. Indeed social cooperatives do not provide their workers only with monetary incentives 
and extrinsic motivations like career opportunities and job security, but they mainly support intrinsic motivations by giving employees autonomy, keeping alive their interest in the activities they perform, ensuring social and personal recognition, fairness in wages and treatment, and also satisfying the need for good relationships with superiors and peers. The high level of autonomy, interest, and involvement (as declared by more than 75 per cent of workers) compensates for the fact that social cooperatives tend to pay salaries that are quite low (on average 1,100 Euros per month for full-time workers), especially compared to the salaries of public employees.

The crucial role displayed by umbrella organizations

Since their very first years of development, one of the main strategies adopted by social cooperatives has been, not to increase the size of the individual cooperative to match the growing demand for services, but to spin-off new initiatives and create local consortia. The choice of benefiting from the advantages of large size by grouping into consortia allowed to pursue a specialisation strategy. A consortium can be defined as an inter-organizational agreement which requires an intermediate level of coordination among enterprises' (Pavolini, 2003). It is therefore the main form of collaboration among cooperatives which join together in pursuit of business and productive ends. As such, consortia are one of the most important integration forms for social cooperatives. They supply services aimed at supporting members' capacities and management activities with respect to both internal functions (including, for instance, support services to individual cooperatives, mainly in the form of training, technical-administrative services etc) and external functions (including project planning and coordination, bids for tender and participation in other forms of public funding procurement etc). Consortia are formed mainly at the provincial level and then again at the national level; in year 2008 the total number of social cooperative consortia was 269 (Carpita, Andreaus, Costa and Carini, 2011).

\section{Conclusions}

Social enterprises can contribute to supporting socio-economic development. They can indeed speed up growth and strengthen social cohesion at local level. In several EU countries, social enterprises have proved to be an innovative organizational form. They have demonstrated to be better able than public agencies, conventional enterprises and traditional non-profit organizations to match the evolution of demand for general-interest services especially on the part of less wealthy users. The idea that arose in the 1980s of adopting some entrepreneurial models for activities with marked social content, thereby directly involving not only workers, but civil society generally in the management of these new enterprises, seems to have met with success, improving thus supply and efficiency in a sector where it is not possible to rely on technological innovation. 
Significant differences are to be noticed among countries and localities as concerns the diffusion of social enterprises when compared with alternative institutional settings - i.e. public and for-profit arrangements.

In light of the theoretical studies carried out, the practice of social enterprises in Central Eastern Europe and South Eastern Europe, and the more structured experience of such institutions in Europe, it seems that the success of the social enterprise model can be traced back to a number of crucial issues, including among others the existence of a favourable legal environment; the envisagement of a wide set of activities that can be carried out by social enterprises; the implementation of a set of industrial policies that are consistent with the features of social enterprises; access to funding; and a clear definition of partnership policies between public agencies and social enterprises.

The existence of an ad hoc legislation is an important but not sine qua non condition for the development of social enterprises, when the existing legal forms (e.g. associations and cooperatives) allow for the provision of general interest services to the community. The high degree of permissibility of conducting economic activity by non-profit organizations (e.g. associations and foundations are allowed to conduct economic activities as primary activity) and/or the generalinterest orientation of cooperatives appear as important pre-conditions, which have paved the way for the development of social enterprises as associations or cooperatives. The existence of a social enterprise law can contribute to support the growth of the sector, provided that it clarifies goals and constraints social enterprises are expected to comply with.

The envisagement of a wide set of activities that can be carried out by social enterprises is a key precondition, which can allow for the full exploitation of the potential of social enterprises, which are likely to work in any field of activity that is of interest to the entire community or to specific fragile groups of the population. Eligible activities should not be limited to work integration, but ought to include also the provision of social services addressed to the entire community with the possibility of expanding in innovative fields (eg culture, environment, local development, etc.

Industrial policies should be consistent with the features of social enterprises; including for instance the non taxability of profits moved to the assets locked, the provision of consulting services and targeted incentives for the activities performed (e.g. work integration).

Access to funding should be made available for both start-ups through seeds money and investments, especially when social enterprises face capitalization difficulties.

Finally, against the background of promoting cooperative rather than competitive relations between public agencies and social enterprises, clear partnership policies should be defined. 


\section{References}

Anheier, H. K. (2005) Non-profit Organizations, Theory, Management, Policy. London and New York: Routledge.

Bacchiega, A. and C. Borzaga (2003) 'The Economics of the Third Sector: Towards a more Comprehensive Approach' In Anheier, H. K. and A. Ben-Ner (eds.) The Study of The Nonprofit Enterprise, Theories and Approaches, 3-26. Dordrecht: Kulwer.

Borzaga, C and L. Becchetti (2011) The Economics of Social Responsibility: The world of Social Responsibility. London: Routledge.

Borzaga, C., G. Galera and R. Nogales (eds.) (2008) Social Enterprise: A New Model for Poverty Reduction and Employment Generation. Bratislava: UNDP Regional Bureau For Europe and the Commonwealth of Independent States. Borzaga C. (1988) 'La cooperazione di solidarietà sociale: prime riflessioni su un settore emergente'. In Carbonaro, A. and S. Gherardi (eds.) 'I nuovi scenari della cooperazione in Italia: problemi di efficacia, efficienza e legittimazione sociale', Sociologia del Lavoro, 30-31 (Angeli):266-301.

Borzaga C. And G. Failoni (1990) 'La cooperazione di solidarietà sociale in Italia'. Cooperazione e Credito 128:273-297.

Borzaga C. and J. Defourny (2001) The Emergence of Social Enterprise. London: Routledge.

Borzaga, C and A. Ianes (2006) L'Economia della Solidarietà. Storia e Prospettive della Cooperazione Sociale. Roma: Donzelli Editore.

Borzaga, C. and E. Tortia (2007) 'Social Economy Organizations in the Theory of the Firm' In Noya, A. and E. Clearence (eds.) The Social Economy. Building Inclusive Economies, 23-53: OECD Publications.

Defourny, J. (2004) 'Social Enterprises in an Enlarged Europe', Paper presented at the $2^{\text {nd }}$ European Social Economy Conference, October 28-29.

Defourny, J. and M. Nyssens (eds.) (2008) 'Social enterprise in Europe: Recent Trends and Developments'. EMES Working Papers no. 08/01

Dilulio, J. (1996) 'Help Wanted: Economists, Crime and Public Policy', The Journal of Economic Perspectives, American Economic Association, 10 (1):3-24. Elstub, S. (2006) 'Towards and Inclusive Social policy for the UK: The Need for democratic Deliberation in Voluntary and Community Associations', Voluntas, 17(1):17-39.

Evers, A. (1998) ‘Consumers, Citizens and Co-producers' In Floesser, G. and H.U. Otto (eds.) Towards More Democracy in Social Services, 43-51. Berlin and New York: Walter de Gruyter.

Evers, A. and J.L. Laville (2004) The Third Sector in Europe. Cheltenham: Edward Elgar.

Galera, G. (2009) The impact of social enterprises on socio-economic development in transition countries: the cases of Poland and Ukraine. PhD Dissertation.

Galera, G. (2010) 'Social enterprises and work-integration' In Becchetti, L. and

C. Borzaga (eds.), The Economics of Social Responsibility, 105-122. London: 
Routledge.

Glennerster, H. and J. Midgley (1991) The Radical Right and the Welfare State: An International Assessment. Savage, MD: Barnes and Noble.

Global Entrepreneurship Monitor (2004) Global Entrepreneurship Monitor: Focus on Social Entrepreneur. London Business School.

IRIS Network (2012) Rapporto Impresa Sociale 2012, forthcoming. IRIS Network. Kerlin, J. (2006) 'Social Enterprise in the United States and Europe: Understanding and Learning from the Differences', Voluntas, 17(3):246-262.

Leś, E. and M. Jeliazkova (2007) 'The Social Economy in Central East and South East Europe' In Clarence, E. and A. Noya (eds.) The Social Economy. Building Inclusive Economies, Paris: OECD Publishing.

Levi, Y. (1999) 'Community and Hybrid Multi-Stakeholder Co-operatives: A. Comparison', Review of International Co-operation, 92: 83-94.

Monzòn Campos, J.L. (1997) 'Contributions of the Social Economy to the General Interest' In 'Structural Changes and General Interest: Which paradigms for the public, social and co-operative economy?' Annals of Public and Co-operative Economics, 68 (3):397-408.

Pankoke, E. (2004) 'Voluntary Associations and Civic Engagement: European Traditions, Discourses and Perspectives for Voluntary and Intermediary Networks' In Zimmer, A and E. Priller (eds.) Future of Civil Society, 57-76. Wiesbaden: VS Verlag Für Sozialwissenschaften.

Pavolini, E. (2003) Le nuove politiche sociali. I sistemi di Welfare fra istituzioni e società civile. Bologna: Il Mulino.

Rodger, J. J. (2000) From a Welfare State to a Welfare Society, Houndmills, Basingstoke. Hampshire and London: Macmillan Press.

Taylor, M. (2004) 'The Welfare Mix in the United Kingdom' In Evers, A. and J.L. Laville (eds.) The Third Sector in Europe, 122-143. Cheltenham: Edward Elgar. Todev, T., J. Brazda and R. Schediwy (1993) 'Quo vadis cooperative Movement in Eastern Europe?' In Economic Changes in Eastern Europe: Quo vadis Cooperative Movement?, 41-48. Berlin: Berliner Hefte zum internationalen Genossenschaftswesen 1, Veröffentlichung des Instituts für Genossenschaftswesen an der Humboldt-Universität zu Berlin.

Walzer, M. (1998) ‘The Concept of Civil Society' In Walzer, M. (ed.) Toward a Global Civil Society, 7-27. Oxford: Berhahn Books. 